\title{
Grumixama (Eugenia brasiliensis Lam.) cultivated in the Cerrado has high content of bioactive compounds and great antioxidant potential
}

\author{
KaWai Xu1 (D) Aline Medeiros Alves-Santos ${ }^{2}$ iD Tiago Dias ${ }^{2}$ (D) Maria Margareth Veloso Naves $^{2^{*}}$ (D) \\ ${ }^{1}$ Department of Nutritional Science, University of Surrey, Guildford, Surrey, United Kingdom. \\ ${ }^{2}$ Faculdade de Nutrição, Universidade Federal de Goiás (UFG), 74.605-080, Goiânia, GO, Brazil. E-mail: mmvnaves@gmail.com. \\ ${ }^{*}$ Corresponding author.
}

ABSTRACT: Grumixama (Eugenia brasiliensis Lam.) is a Brazilian berry native to the Atlantic Rainforest. Information on nutritional and bioactive profiles of the fruit cultivated in the Brazilian Savannah (Cerrado) is not available in literature. The aim of this study was to investigate the physical and proximate composition; mineral, total phenolics, total tannins and total carotenoids contents; and antioxidant capacity (DPPH and FRAP assays) of the dark purple grumixama cultivated in the Cerrado area (Goiás State). Results showed a similar physical and proximate composition to those of grumixama native to the Atlantic Rainforest. However, grumixama from Cerrado presented the highest dietary fiber and magnesium contents. In addition, the Cerrado grumixama showed higher content of total phenolics (with a large amount of tannins), carotenoids and antioxidant capacity than those of grumixama native to the Atlantic Rainforest, cherry, blueberry, and fruits native to the Cerrado. Thus, the consumption of whole fruit (peel, pulp and seed) in healthy diets and its use as an ingredient for functional food products should be encouraged.

Key words: Eugenia brasiliensis Lam., nutrients, bioactive compounds, polyphenols, antioxidant activity.

Grumixama (Eugenia brasiliensis Lam.) cultivada no Cerrado possui altos teores de compostos bioativos e elevado potencial antioxidante

RESUMO: Grumixama (Eugenia brasiliensis Lam.) é uma 'berry' nativa da Mata Atlântica. Informações sobre o perfil nutricional e bioativo do fruto cultivado no Cerrado não estão disponíveis na literatura. O objetivo deste estudo foi investigar a composição física e centesimal; o conteúdo em minerais, fenólicos totais, taninos totais e carotenoides totais; e a capacidade antioxidante (ensaios DPPH and FRAP) da grumixama roxa cultivada na região do Cerrado (Estado de Goiás). Os resultados mostraram uma composição fisica e centesimal similar à da grumixama nativa da Mata Atlântica. Entretanto, a grumixama cultivada no Cerrado apresentou teores de fibra alimentar e magnésio superiores. Além disso, a grumixama do Cerrado apresentou maiores teores de compostos fenólicos totais (com grande quantidade de taninos) e carotenoides e maior capacidade antioxidante do que os teores da grumixama nativa da Mata Atlantica, cereja, mirtilo e frutos nativos do Cerrado. Assim, o consumo do fruto inteiro (casca, polpa e semente) em dietas saudáveis e seu emprego como ingrediente em produtos alimentícios funcionais devem ser estimulados.

Palavras-chave: Eugenia brasiliensis Lam., nutrientes, compostos bioativos, polifenóis, atividade antioxidante.

\section{INTRODUCTION}

Grumixama (Eugenia brasiliensis Lam.) is a berry native to the Brazilian Atlantic Rainforest. There are three main varieties of grumixama plants distinguished by their fruit colours: dark purple fruit, red fruit and white/yellow fruit. Each fruit has one or two seeds and its pulp has a sweet and sour taste. In Brazil, grumixama is commercially produced in the south and southeast regions of Brazil, which is harvested between November and February, and also used in public gardens and afforestation programs (TEIXEIRA et al., 2018). Grumixama is available commercially as frozen fruit and frozen pulp for juice or jelly (AGUIAR et al., 2016). In addition, the use of the peel of the purple grumixama and jambolão
(Syzygium cumini (L.) Skeels) has been reported as a raw material to extract natural dye for food industry (SANTIAGO et al., 2016).

Although there is limited research about the phytochemical composition of the grumixama fruit, it is known for having a great polyphenol profile and antioxidant capacity, which can contribute to promoting health by reducing the risk of chronic disease development (ARAÚJO et al., 2019). The main bioactive compounds presented in the fruit are phenolic compounds, mainly flavonoids and ellagitannins (TEIXEIRA et al., 2015). Other phytochemical compounds, such as carotenoids, are also reported in purple grumixama, mainly all-trans$\beta$-cryptoxanthin (SILVA et al., 2014). 
Data on the chemical and physical composition and the polyphenol profile of grumixama can vary significantly due to the bioma where the fruit was grown. The Brazilian Atlantic Rainforest, the native region of grumixama, generally has a very high precipitation rate most of the year, and the climate varies in different types of forest areas (SALEMI et al., 2013). In contrast, the Cerrado region has an different climate, characterized by a strong separation of wet and dry (from May to October) seasons (CIANCIARUSO \& BATALHA, 2008), which can affect the fruit quality and chemical composition. Considering the importance of its potential benefits to human health and the lack of information in current scientific literature, the present study aimed to investigate the physical and proximate composition, mineral content, phytochemical profile and antioxidant capacity of the dark purple grumixama grown in the Cerrado region.

\section{MATERIALS AND METHODS}

\section{Materials}

The grumixama fruit was harvested in a commercial orchard in the Leopoldo de Bulhões municipality, located near Goiânia, the capital of the Goiás State. The fruit was collected from different plants of the orchard in November 2018. Mature and injury free fruits were selected and transported to the laboratory, where they were washed with water and sodium hypochlorite, frozen and stored at $-20{ }^{\circ} \mathrm{C}$. The whole fruit (peel, pulp and seed) was freeze dried and the sample was homogenized in an analytic mill (A11, IKA) to obtain a powder, which was stored in polyethylene packages and kept at 4 ${ }^{\circ} \mathrm{C}$ for further analyses.

\section{Physical characteristics and proximate composition}

The total soluble solid was measured by a refractometer $(076780$, Quimis) and the $\mathrm{pH}$ was evaluated using a $\mathrm{pH}$ meter (AD1000, Adwa). The citric acid content was determined according to INSTITUTO ADOLFO LUTZ (2005) and expressed as $\mathrm{g} / 100 \mathrm{~g}$. The proximate composition was determined by the analysis of moisture, total nitrogen (by microKjeldahl method) converted to protein, ash and total dietary fiber, according to AOAC (2012); and lipid, as described by BLIGH \& DYER (1959). Carbohydrate content was estimated by the difference between 100 and the sum of the other components. Results were expressed as $\mathrm{g} / 100 \mathrm{~g}$. The total energy was obtained using the Atwater factors of 4,4 and $9 \mathrm{kcal} / \mathrm{g}$ for protein, carbohydrate and lipid, respectively.

\section{Mineral content}

Samples were incinerated in a muffle furnace at $550^{\circ} \mathrm{C}$, and then the ashes were solubilized in concentrated hydrochloric acid. Contents of calcium, iron, magnesium, phosphorus and zinc were quantified by atomic absorption spectrometry, and sodium and potassium by atomic emission using a spectrometer (AAnalyst-200, Perkin Elmer) (AOAC, 2012). Results were expressed as $\mathrm{mg} / 100 \mathrm{~g}$ of fresh weight.

\section{Extract preparation}

Extracts were prepared with $0.5 \mathrm{~g}$ freeze dried sample and $25 \mathrm{~mL}$ of $50 \%$ methanol solution, for total phenolic and antioxidant capacity analyses; and with $0.5 \mathrm{~g}$ freeze dried sample and $25 \mathrm{~mL}$ of $100 \%$ methanol, for total tannin analysis; using an ultrasound bath at $25{ }^{\circ} \mathrm{C}$ for $1 \mathrm{~h}$. The solution obtained was centrifuged at $4000 \mathrm{rpm}$ and $25^{\circ} \mathrm{C}$ for $10 \mathrm{~min}$. The supernatant was collected and used for the respective analysis.

\section{Total phenolic and total tannin contents}

The total phenolic content was analyzed according to SINGLETON \& ROSSI (1965) using Folin-Ciocalteau reagent, and it was quantified using a standard curve for gallic acid (Concentration = $[$ Absorbance +0.0017$] / 0.0067 ; \mathrm{r}=0.9982)$ at 765 $\mathrm{nm}$ by a UV/Visible spectrophotometer (V-630, Jasco). The result was expressed as $\mathrm{mg}$ of gallic acid equivalents (GAE)/100g of the sample (fresh and dry weight). The total tannin content was analyzed as proposed by AOAC (2012). Aliquot of $0.05 \mathrm{~mL}$ of extract was diluted by $4.20 \mathrm{~mL}$ of distilled water. Then, $0.25 \mathrm{~mL}$ of Folin-Denis reagent and $0.5 \mathrm{~mL}$ of sodium carbonate solution $(35 \%)$ were added. The mixture was incubated for $30 \mathrm{~min}$ at room temperature. The absorbance was measured at $760 \mathrm{~nm}$, by a UV/ Vis spectrophotometer (V-630, Jasco). Tannic acid was used as the standard for the calibration curve (Concentration $=[$ Absorbance -0.0144$] / 10.185 ; \mathrm{r}$ $=0.9963)$. The result was expressed as $\mathrm{mg}$ of tannic acid equivalents (TAE)/100 $\mathrm{g}$ of the sample (fresh and dry weight).

\section{Total carotenoid content}

Aliquots of $1.0 \mathrm{~g}$ of sample were homogenized with $35 \mathrm{~mL}$ of acetone at $4{ }^{\circ} \mathrm{C}$ for the extraction of carotenoids. Extracts were vacuumfiltered several times until they became colorless. They were then washed successively with petroleum ether and distilled water in a separatory funnel until the maximum removal of acetone. The resulting ether 
fraction was dried with anhydrous sodium sulfate and transferred to a volumetric flask completed up to $100 \mathrm{~mL}$. UV/Vis spectrophotometric (V-630, Jasco) scanning was performed between 350 and $700 \mathrm{~nm}$ (RODRIGUEZ-AMAYA, 2001). The highest absorbance of wave-length $(447 \mathrm{~nm})$ was employed to determine total carotenoid content, in $\mu \mathrm{g} / \mathrm{g}$ of the sample (fresh and dry weight), according to the equation:

Total carotenoid content $\mu \mathrm{g} / \mathrm{g}=\frac{\text { Absorbance } \times \text { Volume }(\mathrm{mL}) \times 10^{4}}{A_{1 \mathrm{~cm}}^{1 \%} \times \text { sumple weight }(\mathrm{g})}$ Where $A_{1 \mathrm{~cm}}^{1 \%}$ is absorption coefficient of $\beta$-carotene in petroleum ether (2592).

\section{Antioxidant capacity}

The DPPH (2,2-diphenyl-1-picrylhidrazila) radical scavenging method was carried out according to BRAND-WILLIAMS et al. (1995) at $517 \mathrm{~nm}$. The ferric reducing antioxidant power (FRAP) assay was analyzed by BENZIE \& STRAIN (1996) at $595 \mathrm{~nm}$. Trolox was used as the standard for the calibration curves (DPPH: Concentration = [0.6107 - Absorbance]/0.0006, $\mathrm{r}=-0.9986$; FRAP: Concentration $=[$ Absorbance -0.0293$] / 0.0011 ; \mathrm{r}$
$=0.9979)$. The antioxidant capacity was expressed as $\mu \mathrm{mol}$ of Trolox equivalents (TE)/g of the sample (fresh and dry weight).

\section{RESULTS AND DISCUSSION}

Few studies on physical and proximate composition of grumixama were reported in literature. As the fruit is native to the Atlantic Rainforest region, the studies were done using the fruit produced in that area, thus, this study seems to be the first one to present data about grumixama cultivated in the Cerrado region. Data of grumixama cultivated in the Goiás State (Cerrado region), and the corresponding data of grumixama from other states of the Atlantic Rainforest region (Rio de Janeiro, São Paulo, Santa Catarina and Minas Gerais-Ouro Preto) suggest variations on the physical and chemical composition of grumixama cultivated in different climate conditions (Table 1). It was found that the grumixama fruit from Goiás has a higher citric acid content (1.16 $\mathrm{g} / 100 \mathrm{~g}$ fresh weight) and lower $\mathrm{pH}$ (3.39) than those of the fruit from Rio de Janeiro $(0.29 \mathrm{~g} / 100 \mathrm{~g}$ fresh weight; 4.34, respectively) (AGUIAR et al., 2016).

Table 1 - Comparison of proximate composition and mineral contents (fresh weight) of grumixama cultivated in the Cerrado (Goiás State) with grumixama grown in different Brazilian States of the Atlantic Rainforest region.

\begin{tabular}{|c|c|c|c|c|c|}
\hline Grumixama & $\begin{array}{c}\text { Goiás } \\
\text { (whole fruit, fresh } \\
\text { weight) }\end{array}$ & $\begin{array}{l}\text { Rio de Janeiro } \\
\text { (pulp) }\end{array}$ & $\begin{array}{l}\text { São Paulo } \\
\text { (pulp) }\end{array}$ & $\begin{array}{l}\text { Santa Catarina } \\
\text { (pulp) }\end{array}$ & $\begin{array}{l}\text { Ouro Preto-MG } \\
\text { (pulp) }\end{array}$ \\
\hline \multicolumn{6}{|c|}{ 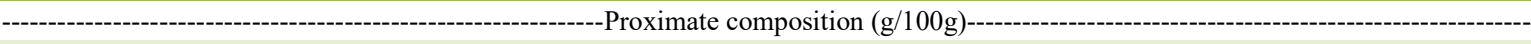 } \\
\hline Moisture & $82.96 \pm 0.10$ & - & $86.55 \pm 0.34$ & $85.64 \pm 0.20$ & $90.15 \pm 0.97$ \\
\hline Carbohydrate & $9.07 \pm 0.29$ & - & 8.25 & 9.51 & 7.83 \\
\hline Protein & $0.71 \pm 0.06$ & - & $0.58 \pm 0.01$ & $0.58 \pm 0.01$ & $0.39 \pm 0.01$ \\
\hline Lipid & $0.72 \pm 0.19$ & - & $0.24 \pm 0.01$ & $0.17 \pm 0.16$ & $0.02 \pm 0.01$ \\
\hline Ash & $0.60 \pm 0.01$ & - & $0.50 \pm 0.01$ & $0.46 \pm 0.02$ & $0.36 \pm 0.00$ \\
\hline Total dietary fiber & $5.94 \pm 0.17$ & - & $3.88 \pm 0.18$ & $3.64 \pm 0.09$ & $1.25 \pm 0.05$ \\
\hline Energy value $(\mathrm{kcal} / 100 \mathrm{~g})$ & $45.60 \pm 0.92$ & - & 37.48 & 41.89 & 33.06 \\
\hline \multicolumn{6}{|c|}{ - } \\
\hline Calcium $(\mathrm{Ca})$ & $29.86 \pm 6.80$ & 19.80 & - & - & - \\
\hline Magnesium (Mg) & $22.57 \pm 1.46$ & 0.07 & - & - & - \\
\hline Iron $(\mathrm{Fe})$ & $0.32 \pm 0.11$ & 0.52 & - & - & - \\
\hline Potassium (K) & $201.63 \pm 1.49$ & 160.00 & - & - & - \\
\hline Sodium $(\mathrm{Na})$ & $1.93 \pm 0.03$ & 1.00 & - & - & - \\
\hline Zinc $(\mathrm{Zn})$ & $0.22 \pm 0.01$ & 0.14 & - & - & - \\
\hline Phosphorus (P) & $1.93 \pm 0.01$ & - & - & - & - \\
\hline
\end{tabular}

Values are presented as mean \pm standard deviation of three replicates. References of grumixama data from each State: Goiás (present study); Rio de Janeiro (AGUIAR et al., 2016); São Paulo and Santa Catarina (TEIXEIRA et al., 2015); and Ouro Preto-MG (ZOLA et al., 2019) 
Soluble solid content of grumixama from Goiás (2.85 ${ }^{\circ}$ Brix) was higher than those of the fruits from São Paulo (1.35 ${ }^{\circ}$ Brix) and Santa Catarina (1.35 ${ }^{\circ}$ Brix $)$ (TEIXEIRA et al., 2015), but lower than that of grumixama from Ouro Preto $\left(5.00^{\circ} \mathrm{Brix}\right)$ (ZOLA et al., 2019).

Grumixama from Goiás has a carbohydrate content and energy value comparable to those of the fruits from São Paulo, Santa Catarina(TEIXEIRAetal., 2015) and Ouro Preto (ZOLA et al., 2019). However, it contains the lowest moisture concentration, which could be explained by the lack of precipitation in the dry season, which typically ranges from May to October in the Cerrado region. Moisture and total sugar contents can be altered by the environment conditions during maturation (ARAÚJO et al., 2019), which in a dryer environment could reduce fruit size and weight, with augmented sugar content (GUIZANI et al., 2019). Indeed, grumixama from Goiás has lower moisture and higher soluble solid content when compared to those of grumixama from São Paulo and Santa Catarina (TEIXEIRA et al., 2015). In addition, grumixama from Goiás presented the highest dietary fiber content compared to those of the fruits grown in other regions of Brazil (Table 1); although, the fruit from Goiás was analyzed as whole fruit. This find is relevant as the consumption of dietary fiber is related to various health benefits, such as maintaining a healthy gut microbiota and lower postprandial insulin response and cholesterol (FULLER et al., 2016). These properties are important in preventing chronic diseases, such as obesity and coronary heart disease. Regarding the protein content, the values of grumixama from all states are comparable, ranging from $0.39 \mathrm{~g}$ (Ouro Preto) (ZOLA et al., 2019) to 0.60 g (Goiás). Moreover, grumixama from Goiás has a relatively high content of lipid and ash; likely due to the sample containing the whole fruit, instead of just the pulp analyzed in the other studies (Table 1).

Due to limited data on grumixama mineral content, our data is compared to those of the fruit cultivated in Rio de Janeiro (AGUIAR et al., 2016) (Table 1). Although, the content of iron, sodium and zinc are comparable between grumixama from both regions, the grumixama from Goiás has higher content of magnesium than that of the fruit grown in Rio de Janeiro (Table 1). In addition, the magnesium concentration of grumixama from Goiás is close to that of avocado (29 mg/100g fresh weight) (DREHER \& DAVENPORT, 2013), which is known as one of the best dietary sources of magnesium in the western diet. An adequate level of magnesium is shown to be important for maintaining electrical, metabolic and cardiovascular homeostasis (SEVERINO et al., 2019). It is also beneficial as a fat absorption inhibitor, which decreases postprandial hyperlipidemia in healthy humans (KISHIMOTO et al., 2009). Moreover, the calcium and potassium contents of grumixama from Goiás are greater than those of the fruit from Rio de Janeiro. Mineral content of the fruits can vary according to the soil mineral content and soil quality (HORNICK, 1992), which could explain the differences between the mineral content of the same fruit cultivated in different regions.

Data about the polyphenol content of grumixama is also scarce in literature. Thus, the data of the present study was compared to those of grumixama from São Paulo (SILVA et al., 2014; INFANTE et al., 2016) and Florida (REYNERTSON et al., 2008), and of fruits native to the Cerrado (cagaita, cerrado cashew and gabiroba). In addition, our results are comparable to fruits that are known as relevant sources of phytochemicals, such as blueberry and cherry (GRACE et al., 2014; OLSZANSKA et al., 2017). Total phenolic content of grumixama from Goiás was significantly higher than those of grumixama from São Paulo, Florida and other fruits, except that of gabiroba (Table 2). The most reported data of grumixama are from its pulp rather than the whole fruit. A study on grumixama from São Paulo (INFANTE et al., 2016) analyzed the fruit seed and found high total phenolics content (4260 mg GAE/100g dry weight). Thus, if INFANTE et al. (2016) had analyzed the whole fruit, the authors would have found a value close to that of the fruit from Goiás. Nevertheless, REYNERTSON et al. (2008) reported lower value of phenolic compounds of whole grumixama from Florida than that of grumixama from Goiás (Table 2).

The total tannin content of grumixama fruit has not yet been reported in literature. However, it had been reported as a fruit high in ellagitannin (82-243 mg ellagic acid equivalents $/ 100 \mathrm{~g}$ fresh pulp) (TEIXEIRA et al., 2015). In the present study, grumixama cultivated in Goiás showed high level of total tannin content (Table 2). This could suggest a high content of proanthocyanidins (condensed tannins); hydrolysable tannins, such as ellagitannin, and other complex tannins. According to the literature, tannins have several health benefits, such as cardiac rhythm and cell functionality modulation (BLADE et al., 2016). In addition, tannins and other complex polyphenols feature prebiotic properties, as they promote the growth of beneficial bacteria in the intestine, and have been associated with lower risk of overweight and obesity (LAMUEL-RAVENTOS \& ONGE, 2017; SUGIZAKI \& NAVES, 2018). 
Table 2 - Bioactive compounds and antioxidant capacity of grumixama cultivated in the Cerrado (Goiás State) in comparison with grumixama cultivated in other Brazilian regions and other similar fruits from the Cerrado region and abroad.

\begin{tabular}{|c|c|c|c|c|}
\hline Parameters & Fruit, Location & Fresh weight & Dry weight & Reference \\
\hline \multirow{9}{*}{$\begin{array}{l}\text { Total phenolics } \\
\text { (mg GAE/100g) }\end{array}$} & Grumixama, GO (whole) & $926.0 \pm 33.0$ & $5434.3 \pm 193.5$ & Presente study \\
\hline & Grumixama, SP (pulp) & $415.1 \pm 22.3$ & - & Silva et al. (2014) \\
\hline & Grumixama, SP (pulp) & - & $2669 \pm 122$ & Infante et al. (2016) \\
\hline & Grumixama, Florida (whole) & - & $2480 \pm 106$ & Reynertson et al. (2008)* \\
\hline & Cagaita, GO (peel and pulp) & $141.95 \pm 2.12$ & - & Alves et al. (2017) \\
\hline & $\begin{array}{c}\text { Cerrado cashew, GO } \\
\text { (pseudofruit- peel and pulp) }\end{array}$ & $160.74 \pm 6.48$ & - & Alves et al. (2017) \\
\hline & Gabiroba, GO (pulp) & $1222.59 \pm 40.31$ & - & Alves et al. (2017) \\
\hline & Czech sweet cherry (whole) & $202.28 \pm 5.81$ & - & Olszanska et al. (2017) \\
\hline & Alaskan wild blueberry (whole) & $504.5 \pm 32.2$ & - & Grace et al. (2014) \\
\hline $\begin{array}{l}\text { Total tannins } \\
\text { (mg TAE } / 100 \mathrm{~g})\end{array}$ & Grumixama, GO (whole) & $797.2 \pm 21.4$ & $4678.5 \pm 125.6$ & Presente study \\
\hline \multirow{2}{*}{$\begin{array}{l}\text { Total carotenoids } \\
(\mu \mathrm{g} / \mathrm{g})\end{array}$} & Grumixama, GO (whole) & $14.95 \pm 0.70$ & $87.71 \pm 4.09$ & Presente study \\
\hline & Grumixama, SP (pulp) & $5.15 \pm 1.96$ & - & Silva et al. (2014) \\
\hline \multirow{6}{*}{$\begin{array}{l}\text { Antioxidant } \\
\text { capacity } \\
(\mu \mathrm{mol} \mathrm{TE} / \mathrm{g}) \\
\text { by } \\
\text { DPPH }\end{array}$} & Grumixama, GO (whole) & $119.0 \pm 2.0$ & $698.5 \pm 11.9$ & Present study \\
\hline & Grumixama, SP (pulp) & - & $81.31 \pm 4.30$ & Machado et al. (2017) \\
\hline & Cagaita, GO (peel and pulp) & 12.00 & - & Alves et al. (2017) \\
\hline & $\begin{array}{c}\text { Cerrado cashew, GO } \\
\text { (pseudofruit- peel and pulp) }\end{array}$ & 10.00 & - & Alves et al. (2017) \\
\hline & Gabiroba, GO (pulp) & 77.00 & - & Alves et al. (2017) \\
\hline & Alaskan wild blueberry (whole) & $46.50 \pm 4.50$ & - & Grace et al. (2014) \\
\hline
\end{tabular}

GAE (gallic acid equivalents); TAE (tannic acid equivalents); DPPH ((2,2-diphenyl-1-picryl-hidrazila); TE (trolox equivalents); FRAP (the ferric reducing antioxidant power); GO (Goiás); SP (São Paulo); Florida, USA. *Values were adapted to unit per 100g.

Based on the result of total carotenoids content, the grumixama cultivated in Goiás showed almost triple the amount of carotenoids when compared to the grumixama cultivated in São Paulo (SILVA et al., 2014). It is worth mentioning that the sunny environment of the Cerrado could have a significant impact on its carotenoid content (RODRIGUEZ-AMAYA, 2001).

Concerning the result of the antioxidant capacity by DPPH (Table 2), the grumixama cultivated in Goiás has the highest radical scavenging capacity among the grumixama cultivated in São Paulo (MACHADO et al., 2017), the fruits native to the Cerrado (ALVES et al., 2017) and Alaskan wild blueberry (GRACE et al., 2014). The grumixama seed has high antioxidant capacity (TEIXEIRA et al., 2015), which could partially explain the significant difference between data of the fruit from São Paulo (pulp) (MACHADO et al., 2017) and Goiás (whole fruit). Nonetheless, the antioxidant capacity of the grumixama from Goiás is still remarkably higher than those of whole fruits, like Alaskan wild blueberry (Table 2). In addition to the DPPH results, the values of FRAP assay observed in the present study were
$132.00 \pm 7.35 \mu \mathrm{mol} \mathrm{TE} / \mathrm{g}$ (fresh weight) and 774.49 $\pm 43.10 \mu \mathrm{mol} \mathrm{TE} / \mathrm{g}$ (dry weight), higher than that of grumixama from São Paulo (117.8 $\mu \mathrm{mol} \mathrm{TE} / \mathrm{g}$, dry weight) (MACHADO et al., 2017); gabiroba from Cerrado (110.2 $\mu \mathrm{mol} \mathrm{TE} / \mathrm{g}$, fresh weight) (ALVES et al., 2017); and Alaskan wild blueberry (100.3 $\mu \mathrm{mol} \mathrm{TE} / \mathrm{g}$, fresh weight) (GRACE et al., 2014). Therefore, the great antioxidant capacity of grumixama was confirmed by more than one assay, as recommended in the literature (LÓPEZ-ALARCÓN \& DENICOLA, 2013).

By comparing the polyphenol content and antioxidant capacity with other fruits, grumixama is a highly valuable fruit due to its polyphenol content, mainly anthocyanin, which is responsible for its purple colour (LAZARINI et al., 2018), and tannins (Table 2). Thus, in vivo studies should be conducted to investigate the beneficial properties of grumixama and its by-products on different metabolic systems, as well as on the gut microbiota.

\section{CONCLUSION}

Dark purple grumixama cultivated in the Cerrado region has high contents of dietary fiber, 
magnesium, total phenolic compounds, tannins and carotenoids, and features great antioxidant potential. This profile stands out from those of fruits native to the Cerrado. Therefore, the consumption of whole fruit (peel, pulp and seed) in healthy diets and its use as an ingredient for functional food products should be encouraged.

\section{ACKNOWLEDGEMENTS}

There was no financial aid for this work.

\section{DECLARATION OF CONFLICT OF INTERESTS \\ The authors declared no potential conflicts of interest with respect to the research, authorship, and/or publication of this article.}

\section{AUTHORS' CONTRIBUTIONS}

KWX carried out the experiments and wrote down the manuscript. AMA-S and TD guided and aided the data collection and revised the manuscript. MMVN conceived and designed the study, and critically reviewed the manuscript. All authors approved the final version of the manuscript.

\section{REFERENCES}

AGUIAR, T. M. et al. Study of grumixama (Eugenia Brasiliensis, Lam) fruit pulp and development of a jelly: rheological, sensorial and colorimetric evaluation. The Natural Products Journal, v.6, n.2, p.142-151, 2016. Available from: $<$ https://doi.org/ 10.2174/2210315506999160506110340>. Accessed: Jan. 27, 2020.

ALVES, A. M. et al. Ascorbic acid and phenolic contents, antioxidant capacity and flavonoids composition of Brazilian Savannah native fruits. Food Science and Technology, v.37, n.4, p.564-569, 2017. Available from: $<$ https://doi.org/ 10.1590/1678457x.26716>. Accessed: Jan. 27, 2020.

AOAC, Association of Official Analytical Chemists. Official methods of analysis. Washington: AOAC International, 2012. $19^{\text {th }} \mathrm{ed}$.

ARAÚJO, F. F. et al. Wild Brazilian species of Eugenia genera (Myrtaceae) as an innovation hotspot for food and pharmacological purposes. Food Research International, v.121, p.57-72, 2019. Available from: <https://doi.org/10.1016/j. foodres.2019.03.018>. Accessed: Jan. 27, 2020.

BENZIE, I. F. F.; STRAIN, J. J. The ferric reducing ability of plasma (FRAP) as a measure of "antioxidant power": the FRAP assay. Analytical Biochemistry, v.239, n.1, p.70-76, 1996. Available from: $<$ https://doi.org/10.1006/abio.1996.0292 >. Accessed: Jan. 27, 2020

BLADE, C. et al. Proanthocyanidins in health and disease. Biofactors, v.42, n.1, p.5-12, 2016. Available from: $<$ https://doi. org/ 10.1002/biof.1249>. Accessed: Jan. 27, 2020

BLIGH, E. G.; DYER, W. J. A. Rapid method of total lipid extraction and purification. Canadian Journal of Biochemistry and Physiology, v.37, n.8, p.911-917, 1959. Available from:<https://doi.org/10.1139/o59-099>. Accessed: Jan. 27, 2020.

BRAND-WILLIAMS, W. et al. Use of a free radical method to evaluate antioxidant activity. LWT - Food Science and Technology, v.28, n.1, p.25-30, 1995. Available from: <https://doi. org/10.1016/S0023-6438(95)80008-5>. Accessed: Jan. 29, 2020.

CIANCIARUSO, M. V.; BATALHA, M. A. A year in a Cerrado wet grassland: a non-seasonal island in a seasonal savanna environment. Brazilian Journal of Biology, v.68, n.3, p.16784375, 2008. Available from: <https://doi.org/10.1590/S151969842008000300005>. Accessed: Jan. 29, 2020.

DREHER, M. L.; DAVENPORT, A. J. Hass avocado composition and potential health effects. Critical Review in Food Science and Nutrition, v.53, n.7, p.738-750, 2013. Available from: <https://doi. org/10.1080/10408398.2011.556759>. Accessed: Jan. 29, 2020

FULLER, S. et al. New horizons for the study of dietary fiber and health: a review. Plant Foods for Human Nutrition, v.71, n.1, p.1-12, 2016. Available from: <https://doi.org/ 10.1007/s11130016-0529-6>. Accessed: Jan. 29, 2020

GRACE, M. H. et al. Comparative analysis of phenolic content and profile, antioxidant capacity and anti-inflammatory bioactivity in Wild Alaskan and commercial Vaccinium Berries. Journal of Agriculture and Food Chemistry, v.62, n.18, p.4007-4017, 2014. Available from: $<$ https://doi.org/10.1021/jf403810y $>$. Accessed: Jan. 29, 2020.

GUIZANI, M. et al. Physiological responses and fruit quality of four peach cultivars under sustained and cyclic deficit irrigation in center-west of Tunisia. Agricultural Water Management, v.217, n.20, p.81-97, 2019. Available from: <https://doi.org/ 10.1016/j. agwat.2019.02.021>. Accessed: Jan. 29, 2020.

HORNICK, S. B. Factors affecting the nutritional quality of crops. American Journal of Alternative Agriculture, v.7, n.1-2, p. 63-68, 1992. Available from: <https://www.jstor.org/ stable/44479652>. Accessed: Jan. 29, 2020.

INFANTE, J. et al. Antioxidant and anti-inflammatory activities of unexplored Brazilian native fruits. Plos One, v.11, n.4, e0152974, 2016. Available from: $<$ https://doi.org/ 10.1371/journal. pone.0152974>. Accessed: Jan. 29, 2020.

INSTITUTO ADOLFO LUTZ. Normas analíticas do Instituto Adolfo Lutz: métodos físico-químicos para análise de alimentos. 4. ed. Brasília: Ministério da Saúde, 2005. 1018 p.

KISHIMOTO, Y. et al. Effects of magnesium on postprandial serum lipid responses in healthy human subjects. British Journal of Nutrition, v.103, n.4, p.469-472, 2009. Available from: $<$ https:// doi.org/ 10.1017/S0007114509992716>. Accessed: Jan. 29, 2020.

LAMUEL-RAVENTOS, R. M.; ONGE, M. P. S. Prebiotic nut compounds and human microbiota. Critical Reviews in Food Science and Nutrition, v.57, n.14, p.3154-3163, 2017. Available from: $<\mathrm{https}: / /$ doi.org/10.1080/10408398.2015.1096763>. Accessed: Jan. 30, 2020

LAZARINI, J. G. et al. Bioprospection of Eugenia brasiliensis, a Brazilian native fruit, as a source of anti-inflammatory and antibiofilm compounds. Biomedicine \& Pharmacotherapy, v.102, p.132-139, 2018. Available from: $<$ https://doi.org/10.1016/j. biopha.2018.03.034>. Accessed: Jan. 30, 2020. 
LÓPEZ-ALARCÓN, C.; DENICOLA, A. Evaluating the antioxidant capacity of natural products: a review on chemical and cellular-based assays. Analytica Chimica Acta, v.763, p.1-10, 2013. Available from: <https://doi.org/ 10.1016/j. aca.2012.11.051>. Accessed: Jan. 30, 2020.

MACHADO, A. P. D. F. et al. Recovery of anthocyanins from residues of Rubus fruticosus, Vaccinium myrtillus and Eugenia brasiliensis by ultrasound assisted extraction, pressurized liquid extraction and their combination. Food Chemistry, v.231, p.1-10, 2017. Available from: <https://doi.org/10.1016/j. foodchem.2017.03.060>. Accessed: Jan. 30, 2020

OLSZANSKA, A. N. et al. Comparison of old cherry cultivars grown in Czech Republic by chemical composition and bioactive compounds. Food Chemistry, v.228, p.136-142, 2017. Available from: $\quad<$ https://doi.org/10.1016/j.foodchem.2017.01.154>. Accessed: Jan. 30, 2020.

REYNERTSON, K. A. et al. Quantitative analysis of antiradical phenolic constituents from fourteen edible Myrtaceae fruits. Food Chemistry, v.109, n.4, p.883-890, 2008. Available from: $<$ https://doi. org/ 10.1016/j.foodchem.2008.01.021>. Accessed: Jan. 30, 2020.

RODRIGUEZ-AMAYA, D. B. A guide to carotenoid analysis in foods. Washington: International Life Sciences Institute (ILSI) Press, 2001. 64 p.Available from: <http://beauty-review.nl/wpcontent/uploads/2014/11/A-guide-to-carotenoid-analysis-in-foods. pdf $>$. Accessed: Jan. 30, 2020.

SALEMI, L. F. et al. Land-use change in the Atlantic rainforest region: consequences for the hydrology of small catchments. Journal of Hydrology, v.499, p.100-109, 2013. Available from: <https://doi.org/ 10.1016/j.jhydrol.2013.06.049>. Accessed: Jan. 30, 2020.

SANTIAGO, M. C. P. A. et al. Characterization of jamelão (Syzygium cumini (L.) Skeels) fruit peel powder for use as natural colorant. Fruits, v.71, n.1, p.3-8, 2016. Available from: <https:// doi.org/ 10.1051/fruits/2015041>. Accessed: Jan. 30, 2020.
SEVERINO, P. et al. Prevention of cardiovascular disease: screening for magnesium deficiency. Cardiology Research and Practice, v. 2019, 2019.Available from: <https://doi. org/10.1155/2019/4874921>. Accessed: Jan. 30, 2020.

SILVA, N. A. et al. Phenolic compounds and carotenoids from four fruits native from the Brazilian Atlantic Forest. Journal of Agricultural and Food Chemistry, v.62, n.22, p.5072-5084, 2014. Available from: <https://doi.org/ 10.1021/jf501211p > Accessed: Jan. 30, 2020.

SINGLETON, V. L.; ROSSI, J. A. Colorimetry of total phenolics with phosphomolybidic- phosphotungstic acid reagent. American Journal of Enology and Viticulture, v.16, n.3, p.144-158, 1965. Available from: < http://www.ajevonline.org/content/16/3/144.full. pdf + html $>$. Accessed: Jan. 30, 2020

SUGIZAKI, C. S. A.; NAVES, M. M. V. Potential prebiotic properties of nuts and edible seeds and their relationship to obesity. Nutrients, v.10, n.11, 1645, 2018. Available from: <https://doi.org/ 10.3390/nu10111645>. Accessed: Jan. 30, 2020.

TEIXEIRA, L. L. et al. Grumixama-Eugenia brasiliensis Lam. In: RODRIGUES, S. et al. Exotic fruits: reference guide. Cambridge: Academic Press, 2018. p.219-224. Available from: $<$ https://www.elsevier.com/books/exotic-fruits-reference-guide/ rodrigues/978-0-12-803138-4>. Accessed: Jan. 30, 2020.

TEIXEIRA, L. L. et al. Identification of ellagitannins and flavonoids from Eugenia brasilienses Lam. (Grumixama) by HPLC-ESI-MS/ MS. Journal of Agriculture and Food Chemistry, v.63, n.22, p.5417-5427, 2015. Available from: <https://doi.org/ 10.1021/acs. jafc.5b01195>. Accessed: Jan. 30, 2020.

ZOLA, F. G. et al. Mineral and centesimal contents, antioxidant activity and antimicrobial action of phenolic compounds from Eugenia brasiliensis Lam, Pulp. Food Science and Technology, v.39, 2019. Available from: <https://doi.org/ 10.1590/fst.18518>. Accessed: Jan. 30, 2020. 